\title{
Available data and risk assessment of the Brazilian threatened species of Combretaceae
}

Viabilidade de dados e avaliação do risco de extinção das espécies

brasileiras ameaçadas de Combretaceae

\author{
Rafael Borges ${ }^{1,3}$, Miguel d'Ávila de Moraes ${ }^{1}$, Nina Pougy Monteiro ${ }^{1}$, Ananda Meinberg Bevacqua ${ }^{1}$, \\ Gustavo Martinelli ${ }^{1,2} \&$ Nilda Marquete ${ }^{2}$
}

\begin{abstract}
The risk assessment is made up of risk analyses of species extinction in a given time, following the International Union for Conservation of Nature and Natural Resources (IUCN) criteria. In Brazil, the data necessary for risk assessments have poor quality, so we proposed the articulation of previous processes to improve data quality. The main objective of this work was to reassess the extinction risk of Brazilian species of Combretaceae previously considered as threatened, updating conservation data available for these taxa. Our results showed that the processes of taxonomic proceedings; data gathering; data analysis; georeferencing and communication improved the assessments consistency, specially due to systematization of the whole process. Of the 11 selected species for reassessment, five were threatened in the categories VU, EN, CR e CR* and six under significant threat of extinction. However the deficiency of herbaria data, the lack of digitalization of the majority of country collections and the limited access to available literature represent the main obstacles for extinction risk assessments of the Brazilian flora Key words: conservation, threatened species, IUCN.

Resumo

A avaliação do risco de extinção consiste em analisar a probabilidade de uma espécie se extinguir em determinado tempo, segundo os critérios da International Union for Conservation of Nature and Natural Resources (IUCN). No Brasil, a baixa qualidade dos dados para a avaliação de risco faz necessária a articulação de processos anteriores para a obtenção de dados suficientes. O objetivo deste trabalho foi reavaliar o risco de extinção das espécies de Combretaceae previamente consideradas ameaçadas de extinção, a partir da atualização dos dados relacionados à conservação destes táxons. Nossos resultados mostram que a articulação dos processos de consolidação taxonômica; importação e análise de dados; georreferenciamento e comunicação otimizaram a obtenção e sistematização de dados, enriquecendo as avaliações. Das 11 espécies selecionadas para reavaliação de risco, cinco encontram-se ameaçadas nas categorias VU, EN, CR e CR* e seis não estão ameaçadas. A integração dos processos e o resultado das avaliações foram consistentes. No entanto a deficiência de informações geográficas nas fichas de herbário, a falta de digitalização da maioria das coleções do País e a dificuldade de acesso a referências bibliográficas representam os principais obstáculos para a categorização do risco de extinção da flora brasileira.
\end{abstract}

Palavras-chave: conservação, espécies ameaçadas de extinção, IUCN.

\section{Introduction}

The Combretaceae family comprehends c. 500 species distributed among 14 genera, with pantropical distribution and the majority of its species occurring at tropical Africa (Stace 2010). The species are trees, shrubs, subshrubs and vines; branches and leaves present indumentum with partitioned, scaled trichomes or pedunculated glands. Leaves are opposite or alternate, simple with entire margins. Inflorescences are disposed in simple or compound spikes (arranged in panicles), capited panicles or racemes. Flowers are monocline, rarely dicline; lower hypanthium involving the ovary and upper

\footnotetext{
${ }^{1}$ Centro Nacional de Conservação da Flora (CNCFlora), PROBIO II, Instituto de Pesquisas Jardim Botânico do Rio de Janeiro, R. Pacheco Leão 915 , 22460-030, Rio de Janeiro, Brazil.

${ }^{2}$ Instituto de Pesquisas Jardim Botânico do Rio de Janeiro, R. Pacheco Leão 915, 22460-030, Rio de Janeiro, Brazil.

${ }^{3}$ Autor para correspondência: rafael@cncflora.jbrj.gov.br
} 
hypanthium in the form of short or long tube; 4-5 sepals and petals, sometimes vestigial or absent; stamens diplostemonous, exserted; disc absent or present, then continuous or lobed; ovary inferior or semi-inferior. Fruits generally $2-5$ winged and seeds with plicated or convoluted cotyledons (Marquete \& Valente 1997).

In Brazil, there are 5 genera 79 species (27 endemic) and 5 varieties ( 3 endemic) that are found in pluvial forests, savannas and mangrove vegetation. The Amazon Rainforest is the biome that contains the highest number of species, followed by the Atlantic Forest, with 53 and 35 respectively (Marquete \& Valente 2010).

Beyond systematic studies, conservation efforts were also undertaken during the work for the publication of global and regional red lists of threatened species. Risk assessments of Combretaceae species were published in the IUCN Red List (IUCN 2010a), in the Brazilian Official List of Flora Threatened Species (MMA 2008) and also in regional red lists such Paraná (SEMA/GTZ 1995) and Espírito Santo (Kollmann et al. 2007) states. However, these initiatives were not articulated or even followed standard protocols; the IUCN and Espirito Santo red lists were prepared following IUCN categories and criteria version 3.1 (IUCN 2001), while the official Brazilian and Paraná red lists presented their own criteria and categories (SEMA/GTZ 1995, MMA 2008). This misalignment prejudices our understanding about the family conservation status in Brazil and difficults the establishment of a robust conservation strategy for the family.

In order to standardize methods and approaches for plant conservation in Brazil, the National Centre for Flora Conservation (CNCFlora) was established in 2008. The initiative aimed to put together a national framework to deal with extinction risk assessments and threatened plant species management. In this way, the main objective of the present work is to reassess the extinction risk of Brazilian species of Combretaceae previously considered as threatened, considering updated conservation data.

\section{Material and Methods}

An scheme of the data updating process is outlined in Figure 1. The nomenclatural status of the 11 taxa previously considered as threatened by Brazilian National Red List (MMA 2008), the Red Lists of Espírito Santo state (Kollmann et al. 2007), Paraná state (SEMA/GTZ 1995) and the Brazilian species included in the official IUCN Red List until 2010 (IUCN 2010a) were checked and validated accordingly to Catálogo de Plantas e Fungos do Brasil (Forzza et al. 2010), The Plant List (2011) and to Combretaceae taxonomy specialists. All respective synonyms were also included in the database. The names were used as keywords for an extensive literature survey: papers, monographies, theses, scientific reports and official documents were considered as valid references and included in the database. The group of taxa compiled was also used to scan herbaria collection for Brazilian Combretaceae records, which were submitted to a thorough process of data cleaning.

The data analysis was carried out after processing the literature surveyed. The CNCFlora team went through the information available filling out the fields on Species Information Service-SIS (IUCN 2009). Despite being a long time consuming process, it represented an important step that gave us a better understating about the information gaps in this taxonomic group. Information reports on each species was then followed to taxonomic specialists, in order to assure data validation. Then, Combretaceae risk assessments were conducted using strictly well-documented data and following the methodology after IUCN (2001).

\section{Results and Discussion}

\section{Collection and herbaria records}

The query to CNCFlora database resulted in 8,318 herbaria records for Combretaceae from 38 different institutions. Most of the collections (83\%) are from Brazilian herbaria (Fig. 2), while the rest are from New York Botanical Garden (765 records),

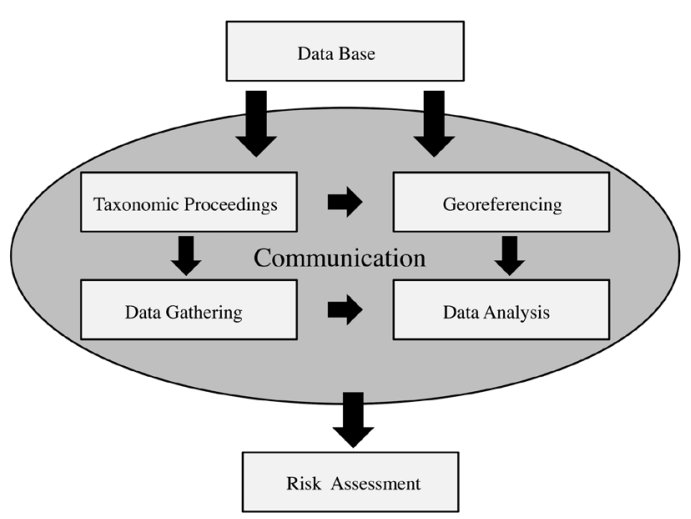

Figure 1 - Scheme of conservation data update until species risk assessment. 
Missouri Botanical Garden (589 records), and Smithsonian National Museum of Natural History (49 records) herbaria. Nevertheless, only $35 \%$ of the collection $(2,907$ records) has been properly georeferenced, preventing its application for spatial analyses and ecological modeling.

The density analyses conduced showed that Combretaceae collection is composed by samples from different biomes widespread throughout the country. The Caatinga (1,592 occurrence records), Atlantic Forest (1,403 occurrence records) and Cerrado (1,684 occurrence records) biomes presented high densities of collections; in spite of that, the Amazon biome had the lower collecting effort of Combretaceae (982 occurrence records) (Fig. 3). Furthermore, the temporal analysis indicates that despite 190 years since the first sample, near $55 \%$ of the collections were made in the last 20 years.

A common problem emerged when trying to analyze together records from different herbarium collections. Determination of samples is normally made by different researchers in a different time, considering comparisons of a different set of samples. Therefore, many times the determination is doubtful and questioned by the scientific community, so, to decide which records are properly determined to establish a species' geographical distribution is challenging. Sometimes, duplicates can have different determinations and a decision to use one or other determination is not trivial and may rely on a revision of herbarium records.

The quality of any botanical research is directly related to proper recognition of the biological entity in nature through appropriate nomenclatural classification. A robust taxonomic treatment and the establishment of valid names and their synonyms are mandatory for any other future study, since

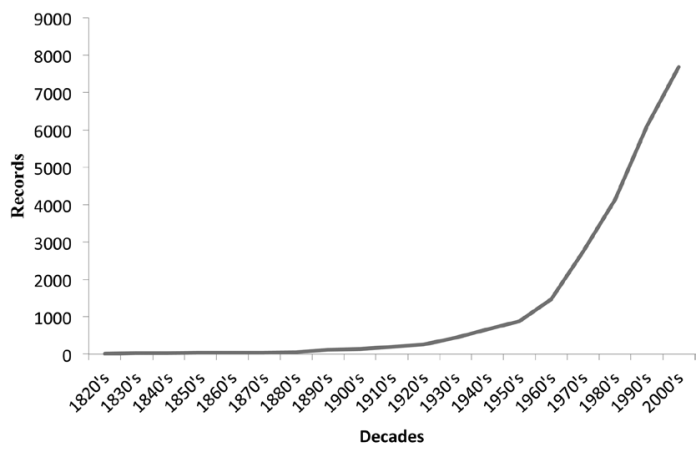

Figure 2 - Number of records of Brazilian Combretaceae in herbaria collections during the XIX and XX centuries. the taxa are used as keywords for herbarium and literature surveys. Herbaria data represent the primary information on species and constitute the baseline for any further research. In this way, during field work and data loading in institutional databases, specialists and field botanists must follow rigorously the standards of data requirements specified by biological collections profiles (i.e. Darwin Core - DwC) to provide a stable standard reference for sharing information on biological diversity (Darwin Core Task Group 2011). Precise data on samples, accordingly to the institutional requirements, are very important to assure usefulness of the collection by different scientific specialties, especially for conservation purposes, which demand an integrative approach.

\section{Brazilian threatened Combretaceae species and the available data}

Previous assessments have pointed 11 Brazilian species of Combretaceae under threat of extinction. They were represented by 17 taxa, out of which 15 are considered as synonyms. The query to CNCFlora database resulted in 464 herbarium



Figure 3 - Density of herbaria records of Brazilian Combretaceae in the country. The darker shaded areas correspond to high density sampling efforts. 
records for the species pointed as threatened by previous efforts. But only 204 (43.9\%) of these records have been precisely georeferenced, with the use of global positioning system devices at the field. Other 114 records $(24.57 \%)$ have been georeferenced posteriorly by CNCFlora team through the use of information included in the locality description. Nevertheless, 136 records had to be georeferenced by the adoption of spatial coordinates of the municipality centroid. Only 10 records were excluded from the analyses, since they represented cultivated individuals. The valid records were used to establish the geographical distribution of the eleven species. The resulting maps illustrate the distribution of each species, which were grouped accordingly their genus (Figs. 4, 5 and 6).

Herbarium records seldom have precise georeferences and that limit its use for conservation action planning. Recent studies have shown that spatial data management through georeferencing techniques may contribute for information refinement (Jones et al. 1997). The adoption of
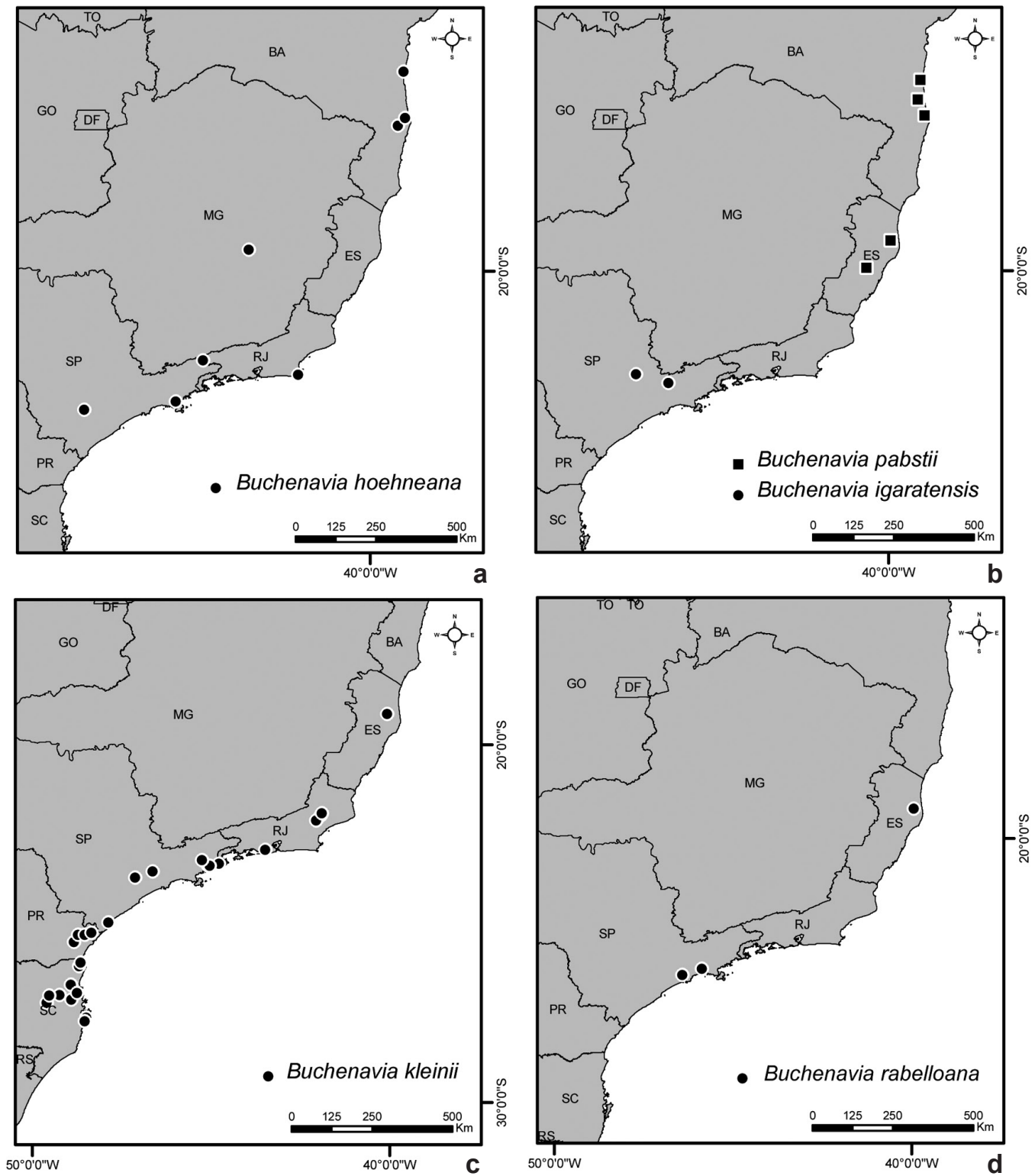

Figure 4 -Map indicating the distribution of Brazilian threatened species of Combretaceae - a. Buchenavia hoehneana; b. Buchenavia pabstii and B. igaratensis; c. B. kleinii; d. B. rabelloana. 
geographical information system and tools is essential for extinction risk pre-assessments and data cleaning, since they can help to integrate distinct information and offer specific perspectives for the researcher responsible for analyzing the data and interpreting the results (Maia 2003).

Other technological tools and a proper information system may help the process of organizing the available information facilitating the process. Normally, information concerning species biology and ecology are scattered in literature
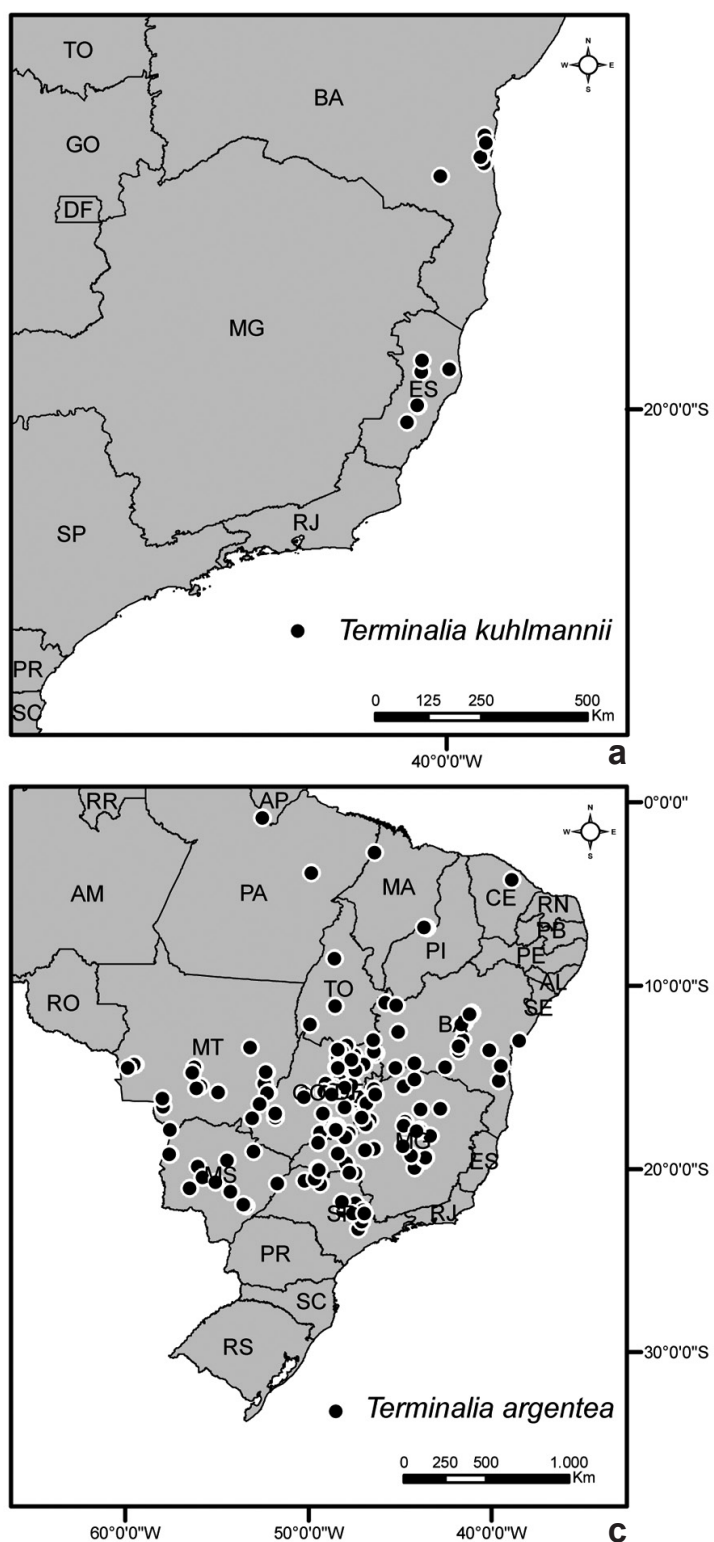

sources, demanding an extra effort to compile it in order to ensure a conservation meaning. After the literature review, 73 references on threatened Brazilian Combretaceae were systematized at the CNCFlora database in order to make their information available for the assessments. There were consulted 34 scientific articles from different journals, 11 theses, 2 books and 1 governmental document that mention the selected species. The great majority of publications dealt with phytosociological, floristic and taxonomical

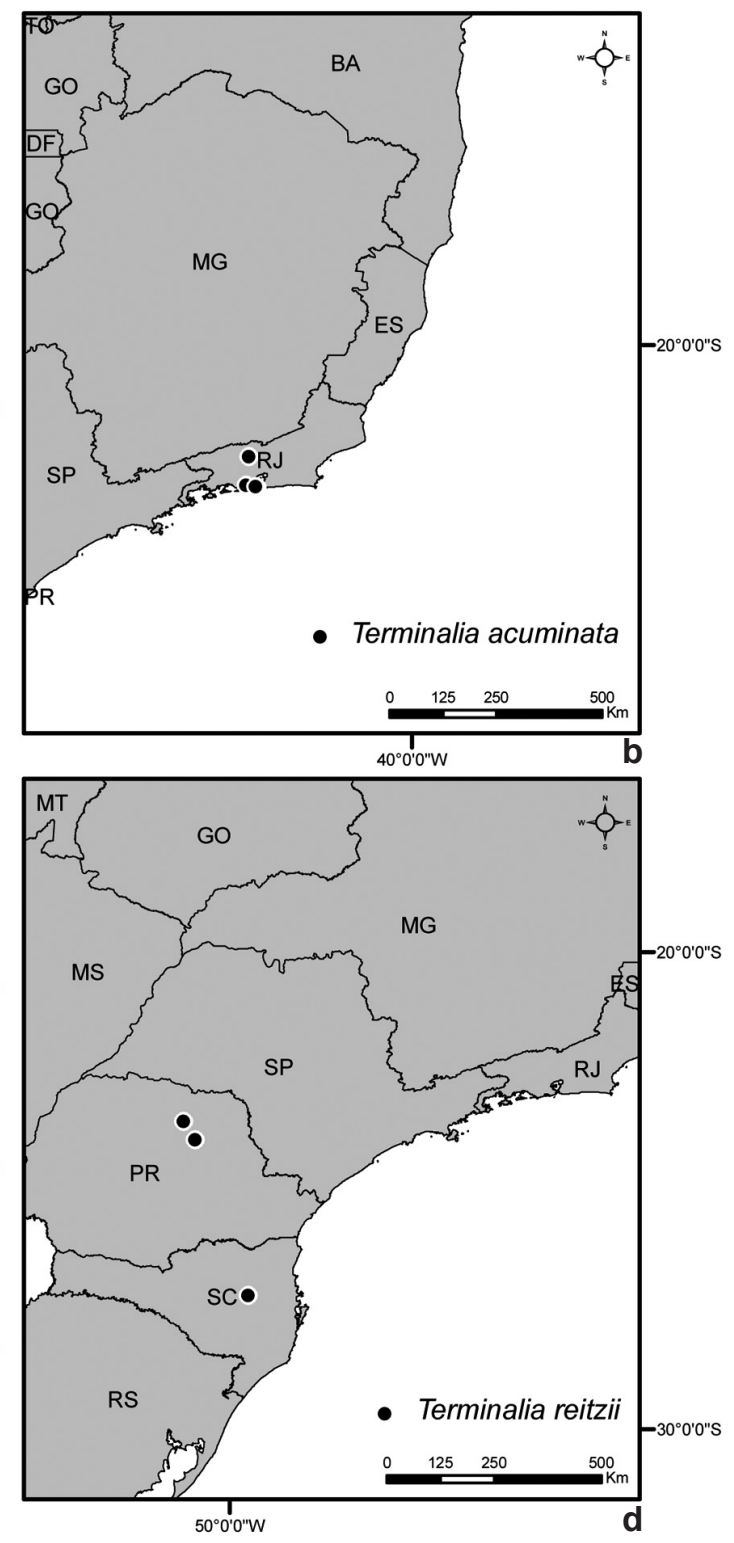

Figure 5 - Map indicating the distribution of Brazilian threatened species of Combretaceae-a. Terminalia kuhlmannii; b. T. acuminata; c. T. argentea; d. T. reitzii. 
aspects of the taxonomic group (Fig. 7a), rather than with ecological ones. Buchenavia kleinii Exell, Terminalia argentea Mart. \& Zucc. and Terminalia januariensis DC. presented more related bibliographic references (Fig. 7b).

\section{Risk assessments}

The assessments provided in this study resulted in category changes compared to previous lists (Tab. 1), but they do not represent genuine alterations. This means that up listing or down listing has been an effect of information access, rather than changes in risk of extinction. For that reason, $40 \%$ (4) of species previously classified as Data Deficient (DD) have been placed in different threat categories in the present assessment. Considering the last official assessment conducted by the scientific academy for the Brazilian government (MMA 2008), four species have been up listed, two species have been down listed and three species were maintained at their previous categories. Despite category changes, the assessments improved in consistency, since all information considered was properly documented and scientifically based, not leaving space to biased categorizations (IUCN 2001).

The majority of species assessed as threatened had their assessment based in IUCN criteria B and D. The first one deals with geographic range, whilst

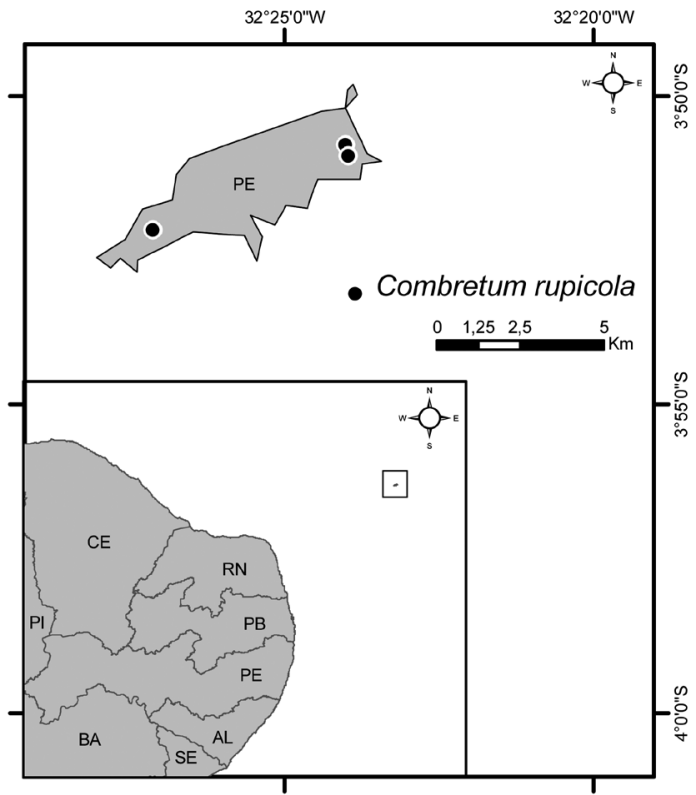

Figure 6 - Map indicating the distribution of Brazilian threatened species ofCombretaceae-Combretum rupicola. the second is related to small population size. Both criteria rely on the interpretation of the specialist on a data set of herbarium records, based on field experience and knowledge on the species biology. The absence of population studies and historical datasets makes difficult any attempt to apply criterion $\mathrm{A}$ - destined for evaluating the effects of population reduction on the species extinction risk, and criterion $\mathrm{C}$ - which deals with population size but demands knowledge on population structure and species reproductive biology (IUCN 2001). The scarcity of ecological and population studies also prevents the application of criterion $\mathrm{E}$, which uses quantitative analysis to show the probability of extinction in the wild.

In order to promote consistent extinction risk assessments, accordingly to IUCN standards, it is important to consolidate a robust database, capable of managing existing scientific information and available updated knowledge on the Brazilian plant species (IUCN 2010b). However, to achieve this quality of assessments it is mandatory a better communication among scientific institutions. Not only to guarantee information flow, but also to promote debates on methods and appropriate
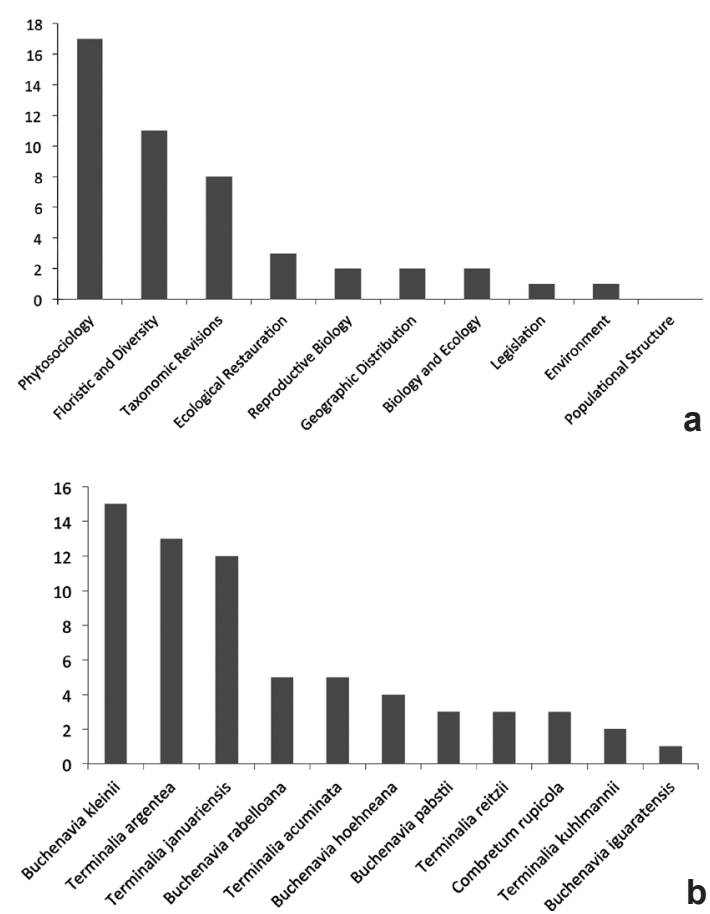

Figure 7 - a. Number of references gathered in relation to type of research; b. number of references gathered per threatened species. 
Table 1 - Extinction risk categories of the species, accordingly to previous assessments and the present study. ES: Espírito Santo state; PR: Paraná state; Bio2005: Biodiversitas (2005); IN6-A1: Governmental resolution - threatened species; IN6-A2: Governmental resolution - data deficient; IUCN: Global assessments accepted by IUCN; PS: Present Study. Threat categories: DD: data deficient; LC: least concern; VU: vulnerable; EN: endangered; CR: critically endangered; $\mathrm{CR}^{*}$ : critically endangered possibly extinct; EW: extinct in the wild; LR/nt: low risk/near threatened; Rara: rare.

\begin{tabular}{|c|c|c|c|c|c|c|c|}
\hline Taxon & ES & PR & Bio2005 & IN6-A1 & IN6-A2 & IUCN & PS \\
\hline Buchenavia hoehneana N.F.Mattos & & & & & & VU & DD \\
\hline Buchenavia igaratensis N.F.Mattos & & & DD & & $\mathrm{X}$ & $\mathrm{EN}$ & DD \\
\hline Buchenavia kleinii Exell & & Rara & & & & $\mathrm{LR} / \mathrm{nt}$ & $\mathrm{LC}$ \\
\hline Buchenavia pabstii Marquete \& C.Valente & EN & & EN & $\mathrm{X}$ & & $\mathrm{EN}$ & DD \\
\hline Buchenavia rabelloana N.F.Mattos & & & VU & $X$ & & EN & EN \\
\hline Combretum rupicolum Ridl. & & & DD & & $\mathrm{X}$ & & $\mathrm{CR}$ \\
\hline Terminalia acuminata (Allemão) Eichler & & & DD & $\mathrm{X}$ & & EW & $\mathrm{CR}^{*}$ \\
\hline Terminalia argentea Mart. & & EN & & & & & VU \\
\hline Terminalia januariensis DC. & & & & & & VU & $\mathrm{LC}$ \\
\hline Terminalia kuhlmannii Alwan \& Stace & EN & & DD & & $\mathrm{X}$ & VU & VU \\
\hline Terminalia reitzii Exell & & & DD & & $\mathrm{X}$ & VU & DD \\
\hline
\end{tabular}

strategies to address the challenge of updating extinction risk assessments of the Brazilian flora.

Considering the Brazilian Combretaceae and our taxonomic knowledge about the family, one of the major challenges to achieve more consistent assessments is to improve the scientific studies on population structure and ecological interactions. In the absence of population ecology researches, phytosociological studies could be important sources of population size data. For instance, using density values per hectare of Buchenavia kleinii and Terminalia januariensis, the population size for these species in their role geographic distribution (Extent of Occurrence) could be inferred. Following Pessoa \& Oliveira (2006) and Aguiar (2003), the estimated population size for B. kleinii is $1-87,775$ individuals, and for T. januariensis (Spolidoro 2001; Kurtz \& Araújo 2000), the estimated population size is $4,502-17,850$ individuals. However, to use phytosociological studies as sources of reliable data, it is extremely important to guarantee the quality of plant sample identification and the precision of population size estimates.

Another barrier verified is the misalignment between national taxonomic efforts and broad family/genera revisions. Accordingly to Marquete \& Valente (2010), all species listed in this study are taxonomic correct. However, Stace (2010) in the revision of the family for the Neotropical region, proposed nomenclatural changes for Buchenavia rabelloana N.F.Mattos, $B$. hoehneana N.F.Mattos, B. pabstii Marquete \& C. Valente, B. igaratensis N.F.Mattos, B. kleinii and T. kuhlmanii. Different nomenclatural classifications puzzle the data compilation of the biological entity and may blur our understanding on the species conservation status.

\section{Acknowledgements}

We would like to thank CNCFlora team and Global Environmental Fund/PROBio for the financial support.

\section{References}

Aguiar, O.T. 2003. Comparação entre os métodos de quadrantes e parcelas na caracterização da composição florística e fitossociológica de um trecho de floresta ombrófila densa no Parque Estadual Carlos Botelho - São Miguel Arcanjo, São Paulo. Dissertação de Mestrado. Universidade de São Paulo, Piracicaba. 218p.

Darwin Core Task Group. 2011. Darwin core terms: a quick reference guide. Available in $<$ http:// rs.tdwg.org/dwc/terms/>. Access in Apr 2011.

Forzza, R.C. et al. 2010. Introdução. In: Lista de espécies da flora do Brasil. Jardim Botânico do Rio de Janeiro. Available in $<$ http://floradobrasil. jbrj.gov.br/2010/>. Access in Apr 2011.

IUCN. 2001. IUCN Red list categories and criteria: version 3.1. IUCN Species Survival Commission. 
IUCN, Gland and Cambridge. 30p. Available in $<$ http://www.iucnredlist.org/static/categories criteria_3_1>.Access in Apr 2011.

IUCN. 2009. IUCN's Species Information Service (SIS). Disponível em <http://www.iucnsis.org >. Access in Apr 2011.

IUCN. 2010a. IUCN Red list of threatened species. Version 2010.4. Available in <www.iucnredlist. org>. Access in Apr 2011.

IUCN. 2010b. Guidelines for using the IUCN red list categories and criteria. Version 8.1. IUCN Standards and Petitions Subcommittee. 85p. Available in <http://intranet.iucn.org/webfiles/ doc/SSC/RedList/RedListGuidelines.pdf.>. Access in Apr 2011.

Kollmann, L. J. C; Fontana, A. P.; Simonelli, M. \& Fraga, C.N. 2007. As angiospermas ameaçadas de extinção no estado do Espírito Santo. In: Simonelli, M. \& Fraga, C. N. (orgs.). Espécies da flora ameaçadas de extinção no estado Espírito Santo. IPEMA, Vitória. Pp. 105-137.

Kurtz, B.C. \& Araújo, D.S.D. 2000. Composição florística e estrutura do componente arbóreo de um trecho de Mata Atlântica na Estação Ecológica Estadual do Paraíso, Cachoeiras de Macacu, Rio de Janeiro, Brasil. Rodriguésia 51: 69-112.

Maia, M.P. 2003. Análise crítica do uso de sistemas de informação geografica - SIG como suporte à gestão APAs no CRA. Estudo de caso:
GisApa Litoral Norte. Dissertação de Mestrado. Universidade de Brasilia, UnB, Brasília. 131p.

Marquete, N.F.S. \& Valente, M.C. 1997. Combretaceae In: Marques, M.C.M. \& Martins, H.F. Flora do estado do Rio de Janeiro. Albertoa 4: 13-51.

Marquete, N. \& Valente, M.C. 2010. Combretaceae. In: Rafaela Campostrini Forzza et al. Catálogo de plantas e fungos do Brasil. Vol. 1. Instituto de Pesquisas Jardim Botânico do Rio de Janeiro, Rio de Janeiro. Pp. 864-866.

MMA - Ministério do Meio Ambiente. 2008. Instrução Normativa $\mathrm{N}^{\circ} 6$ de 23/09/2008.

Pessoa, S.V. \& Oliveira, R.R. 2006. Análise estrutural da vegetação arbórea em três fragmentos florestais na Reserva Biológica de Poço das Antas, Rio de Janeiro, Brasil. Rodriguésia 57: 391-411.

SEMA/GTZ - Secretaria de Estado do Meio Ambiente/Deutsche Gessellschaft fur Technische Zusammenarbeit (SEMA/GTZ). 1995. Lista vermelha de plantas ameaçadas de extinção no estado do Paraná, Curitiba. 139p.

Spolidoro, M.L.C. V. 2001. Composição e estrutura de um trecho de floresta no Médio Paraíba do Sul, RJ. Dissertação de Mestrado. Universidade Federal Rural do Rio de Janeiro, Seropédica. 187p.

Stace, C. 2010. Combretaceae. Flora Neotropica 107, The New York Botanical Garden Press, 374 p.

The Plant List. 2011. The plant list. Available in $<$ http:// www.theplantlist.org>. Access in Apr 2011. 